\title{
Relevance of Financial Performance and Good Corporate Governance Determinant of Sustainaibility Corporate Social Responsibility Disclousure in Islamic Bank in Indonesia
}

\author{
Fitriyah $^{1^{*}}$, Ulfi Kartika Oktaviana ${ }^{2}$ \\ ${ }^{1}$ Faculty of Economic Islamic State University Maulana Malik Ibrahim Malang. \\ ${ }^{2}$ Faculty of Economic Islamic State University Maulana Malik Ibrahim Malang.
}

*Corresponding Author, Email: fitriyah@yahoo.com

\begin{abstract}
The purpose of the paper is to investigate role of the financial performance, ownership structure and number of syari'a supervisory board of Islamic banks in Indonesia on the sustainability of corporate social responsibilities (CSR) disclosure. Ownership structure and number of syari'a supervisory board of Islamic banks as proxy of implementation good corporate governance (GCG). There are seven (7) fully fledge Islamic banks in Indonesia. This study uses logic regression to test empirically whether the CSR is highly influenced by the factors identified earlier. Evidence was found that size, ROA and leverage do not have significant role in corporate social responsibilities (CSR) disclosure. Specifically, the results infer the fact that the CSR disclosures are significant and positively associated to bank size and ownership structure only. The result of the study has confirms the hypothesis that bank size and ROA has positive associated with CSR disclosure. This suggested that large and profitable banks have more resources to devote to social activities. Leverage negatively influences the disclosure of CSR. Thus, lowly leveraged banks will tend to make larger donations than highly leveraged banks. Ownership structure and number of syari'a supervisory board of Islamic banks have positive associated to CSR disclosure. These results also confirm the predictions that good corporate governance mechanism lead to the greater monitoring and thereby greater CSR disclosure.
\end{abstract}

Keywords: Islamic bank, corporate social responsibility (CSR), good corporate governance (GCG), financial performance.

\section{A. INTRODUCTION}

Corporate Social Responsibility is the continuing commitment by business to behave ethically and contribute to economic development while improving the quality of life of the workforce and their families as well as of the local community and society at large. Firm have responsibilities for member of society if they operated within the confines of the law, generated profit and provided employment. In the context of organization CSR is a required investment to create sustainability development for the business, because it offers the companies an opportunity to bridge the "trust gap" among different stakeholders-government, customers, employees, suppliers, investors, etc. CSR is a required investment to create sustainability development for the business, because it offers the companies an opportunity to bridge the "trust gap" among different stakeholdersgovernment, customers, employees, suppliers, investors, etc.

Bank as a financial institution has the same responsibility as the other companies in its commitment towards social problems. Both syariah and conventional banks should be practicing CSR as stipulated by Law No. 40/2007 as part of its primary business activities, which would mean that the stipulation should be implemented with best effort in order to maintain the continuity of the banking institution, the environment and surrounding community. Speaking of CSR practices in 
Islamic banking institution, (Ahmad, 2000) states that such institution conducts its business based on syariah, which is essentially based on the philosophy of Al Qur'an and Sunnah. This would motivate its actors to interact with the environment and their fellow human beings. Considering that this philosophy is a religious one, it is believed that the relations there of would acquire stronger sustainability than conventional CSR patterns. (Dusuki \& Dar, 2005) state that in reality, Islamic banks are expected to play greater role in CSR than conventional banks. The operation of Islamic banks is based on syariah principles, that is the values of transparency and justice, common prosperity, social solidarity, which would be different from conventional banks with their orientation towards profit.

According to Usmani (2002), the principle of Islam sees that business transaction cannot be separated from social responsibility to the community. Several researchers have formulated the normative standard for reporting (Gambling \& Karim, 1986; Baydoun \& Willet, 2000; Lewis, 2001) and social reporting for Islamic business entity based on Islamic principles (Haniffa, 2001; Maali et. al., 2003). The government of Islamic countries such as Malaysia and Indonesia, and international regulatory bodies such as Accounting and Auditing Organization for Islamic Financial Institution (AAOIFI) has also stated their support for the development and adoption of reporting standards for CSR (Sharani, 2004).

According to Hameed and Yahya (2003), Islamic bank as an Islamic business institution is required not only to report its economic performance but also its syariah compliance, social concern and environment concern to its stakeholders. This has been accommodated by the SFA (Statement of Financial Accounting) No. 1 in the Objectives for Financial Accounting for Islamic Banks and Financial Institutions (AAOIFI, 2002). In Indonesia, non-financial reporting has been generally accommodated by PSAK No.1 paragraph 09, which has implicit suggested the need to disclose responsibility on environment and social issues. The quality of accounting information is determined by the coverage of disclosure (Healy \& Palepu, 2001). Disclosure can be mandatory or discretionary/voluntary, including the disclosure on company social responsibility. The disclosure of CSR in Indonesia is mostly voluntary.

Several studies have tried to identify the variables which can explain the variance in CSR disclosure such as Robert (1992), Haniffa et. al., (2002), Sembiring (2005), Gao et. al., (2005), Naser et. al., (2006), Lynes \& Andrachuk (2008), Curuk (2009), Anwar et. al., (2009), Handayani (2010),Joseph \& Taplin (2011) and Rustiarini (2011).

Review on the previous research has identified two factors, which can explain the disclosure of social and environmental responsibility, that is the internal and external factors of the company. The internal factor of the company includes profitability, company size, leverage, the size of board of directors, and ownership structure. The external factors include market system, political system, knowledge system and social system (Lynes \& Andrachuk, 2008). Masruki et. al., (2009) has found that CSR disclosure is related only to bank size for Islamic banks in Malaysia. CSR disclosure is predicted to be capable of improving the relevance of the value of accounting information since CSR disclosure can increase the information required by investors in valuing a company.

Hasan \& Harapan (2010) have explored CSR disclosure by content analysis in Islamic banks from 7 countries, including Indonesia. They found that the CSR disclosure in Islamic banks is above average according to disclosure index. Anugerah (2011) states that the elements of governance corporate structure have simultaneous impact on the coverage of CSR disclosure for banks with a positive coefficient, which can explain $77.5 \%$ of the coverage of banks' CSR disclosure. The study 
by Maali et. al., (2003) indicates that Islamic banks have not played significant role in social activities. According to Usmani (2002), Islamic banks should be able to adopt new financing model, which can support the development of small and mid-sized enterprise. The musharakah financing which is disbursed in stages for small and mid-sized enterprise with its profit sharing plan can support the economic development of common people.

Various reasons for the CSR disclosure in financial industry, especially banking, does not differ much from oilier industries, as reported by the study of Farook et. al., (2011), which examined the factors influencing CSR disclosure for Islamic banks in 14 Muslim countries other than Indonesia. The study found that the existence of shari'a supervisory board, political and social freedom of the community and the magnitude of deposit investment compared to total asset is a significant variable in explaining CSR disclosure.

Based on previous research, the researcher tries to contribute to existing knowledge by focusing in the relevance of financial performance and shari'a supervisory board for CSR disclosure in Islamic banks in Indonesia. Based on the background and problem statement above, the objective of this research is to verify the determining factors of CSR disclosure for Islamic banks in Indonesia. This research is expected to contribute to CSR disclosure of Islamic banking, especially on the relevance between financial performance (size, ROA and leverage) and GCG (ownership structure and number of syari'a supervisory board).

\section{B. METHODOLOGY}

\section{Research Design}

Based on the problems and objective of the research as described above, this research applies the quantitative design. The approach in this research is descriptive one since the objective of this research is to test hypotheses or to answer questions concerning the current issue of the subject under examination. While the characteristics of this research is extended application which is a development of previous studies.

The population of this research is eleven Islamic banks up to the end of 2010. Sample was taken with purposive sampling method. The banks in the sample are Islamic banks, which publish annual financial statements for the period January 2007 through December 2011. Based on these criteria, a sample was constructed, consisting of the following 7 general islamic bank: Bank Muamalat Indonesia, BNI Syariah, Bank Syariah Mandiri, Bank Syariah Mega Indonesia, Bank BRI Syariah, Bank Syariah Bukopin, Bank Victoria Syariah. This research also uses secondary data, which has been collected by other means, that is the data from annual report of each general Islamic bank in the sample and other sources (website and financial report of the company published in the company website or from Indonesia Capital market Directory published by Indonesian Stock Exchange).

In accordance with the problem statement and the hypotheses, the variables studied here can be grouped into two sets:

a. Dependent variable, that is corporate social responsibility. The data for dependent variable is dichotomous, that is banks disclosing CSR and those which are not. Each will be given different notation, where the value for banks not disclosing CSR is zero (0) and otherwise one (1). 
b. Independent variables, that is the variables expected to influence dependent variables, that is:

1) $\mathrm{X} 1$, company size, which is measured as the log of company asset.

Size $=\ln$ (Totall Assets).

According to Adams \& Hardwick (1998) and Brammer \& Millington (2004), in order to minimize and reduce the impact of extreme values, the variable of company size is turned into the natural logarithm (In) of total asset.

2) $X 2$, return on asset $(R O A)$, the ratio for measuring the capability of company in producing net profit based on certain level of assets. (Brigham, 2010). Return on total assets $(R O A)=$ net profit after tax/total current asset.

3) X3, leverage: the ratio, which describes the relation between company debt and total current asset. (Westerfield, 2009).

Debt to total asset ratio $=$ total debt $/$ total current asset.

4) X4, the DPS (Dewan Pengawas Syariah) or Shari'a Supervisory Board/SSB. This variable is categorical, where:

$0=$ there is two member of DPS and;

$1=$ there are more than two members of DPS.

5) XS, ownership structure, ratio of total amount of investment account funds to paid up capital in shareholders equity. (Farook et al., 2011). Ownership structure = investment account holders / paid in capital.

\section{Data Analysis}

The method for data analysis in this research is descriptive analysis. The use of descriptive analysis is required for creating general overview of the data obtained. This general overview can serve as reference for seeing the characteristics of the data obtained. In this research, descriptive analysis is aimed at knowing whether Islamic banks disclosing and not disclosing their CSR can be distinguished from one another based on the involvement of DPS and its financial characteristics (size, leverage and ROA).

Besides using descriptive analysis method, this research also applies multiple regression analysis. The multiple regression is required to predict the impact of two predictor variables or more on a criterion variable or to prove the existence or otherwise of functional relation between two independent variables or more with a dependent variable (Usman, 2003:241). Multiple regression analysis in this research is applied to explore further the relation between DPS involvement, company size, ROA and leverage for Islamic banks between those disclosing and not disclosing CSR for the period 2007-2010.

The method for data analysis in this research is logistic regression since the data for dependent variable is dichotomous (dummy variable) while the independent variable is quantitative of the interval type or ratio and categorical data (Priyatno, 2009). Unlike linear regression, logistic regression does not assume linear relation between independent and dependent variables. Logistic regression is non-linear and the model for logic equation is as follows:

\section{RESULTS AND DISCUSSION}

\section{Definitions of CSR}

Currently there is no consensus on the definition of CSR. The following is some definitions of CSR, 
which is quite widespread and often referred to. The first is Bowen (1953), who has discussed "the obligation of businessman to pursue those policies, to make those decisions or to follow those lines of action which are desirable in terms of the objectives and values of our society."

Wineberg \& Rudolph has defined CSR as "the contribution that a company makes in society through its core business activities, its social investment and philanthropy programs and its engagement in public policy" (Wineberg, 2004:72). Marjono Reksodiputro states that the concept of CSR has some overlap "with the concept of (good) corporate governance and business ethics" (Reksodiputro, 2004). While Schermerhorn (1993) defines CSR as a concern of the business organization to act in their own way in serving the interest of the organization and of the external public (Schermerhorn, 1993).

\section{Stakeholder Theory}

Stakeholder theory states that a company is not an entity, which operates entirely for its own interest but must provide benefit for its stakeholder. In this way, the existence of a company is influenced by the support given by the stakeholders to the company (Ghozali \& Chairi, 2007).

Stakeholder theory predicts that management would pay attention to the expectations of powerful stakeholders, that is the ones powerful enough to control the resources required by the company (Deegan, 2000). This theory can be used for explaining company social responsibility which should be beyond maximizing profit for stakeholder interest and should be higher, that is serving the interest of all parties related or having claim over the company (Untung, 2008 in Waryanti, 2009).

Company would try to satisfy stakeholders by giving required information. The disclosure of corporate social responsibility is a form of company responsibility to the stakeholder. CSR disclosure shows that accounting information is a signal of company's concern with its stakeholder.

\section{Carroll's CSR}

Archie Carroll is one of the proponents of socio-economic view, which relates company social responsibility with ethical responsibility (Carroll, 1979, 1991). The way a company sees and a Carroll pyramid can describe acts on CSR. The concept of CSR pyramid developed by Archie B. Carroll gives theoretical and logical justification of why a company should apply CSR for the community around it. According to Carroll's view, CSR is the top of the pyramid, which is strongly related to and may even be identical with, philanthropic responsibility. According to Carroll, company responsibility consists of four levels that are economic, legal, ethical and discretionary.

Economic responsibility is based on the objective of the company to obtain profit, where a company should be able to produce goods and services valuable to the community, which would enable the company to pay its shareholders and creditor. The government through legal system, which should be complied by the company, determines the legal responsibility. In this matter, the company must abide by whatever rules that bind the company and its operations. According to Carroll, this legal responsibility can be seen as a kind of social contract between the community and business.

Ethical responsibility is the application of existing belief on certain behavior in the society. Ethical responsibility requires the company to operate its business by paying attention to moral values, 
openness and justice (Tan \& Komaran, 2006). Discretionary responsibility is voluntary but the company should treat it as obligatory. This responsibility requires the company to contribute, both in financial and other terms, for the welfare and prosperity of the human beings in general. This responsibility is voluntary or discretionary, so that when the company does not apply it, there would be no sanction from the public, and this is the difference from ethical responsibility (Cochius, 2006).

\section{Agency Theory}

Agency theory states that there is a relation between the principal (company owner or the party giving mandate) and the agent (company manager or the party receiving mandate), which is based on the separation of ownership and control of the company, or the separation between the functions of risk bearing, decision making and control Gense \& Meckling, 1976). Several studies have used the agency theory as the basis for evaluating CSR Agency theory is more focused on the relation between manager and stakeholder, whereby agency theory can explain the incentive problem caused by the separation between manager and owner of resources. This theory believes that the separation between ownership and management would result in agency cost to due conflict of interest (Hossain, Perera \& Rahman, 1995). Agency theory is also related to the agency cost resulting from the conflict between principal and agent (Jensen \& Meckling,1976). The research of Brown et al. (2006) indicates that agency cost plays a role in explaining the magnitude of company donation, which is part of CSR.

\section{CSR in Islamic View}

In Islam, business activity is carried out not only to fulfill material needs and wants but also to carry out religious obligation and to fulfill non-material needs such as social comfort (al-Jawziyyah, 1995; Rahman \& Goddard, 1998). Social responsibility of an organization towards the community consists in protecting and contributing to the prosperity of the community (Beekun, 1997). Social responsibility in Islam is rooted in solidarity and social justice (Naqvi, 1981).

Based on the science of Tauhid, the primary objective of social responsibility is not only responsibility to Allah and human beings but also to the environment. The concept of Tauhid also sees that business activity carried out by human beings is a form of human role as khalifah (leader) in Allah's Earth. Human being as khalifah does not necessarily mean that human beings are free without responsibility, but a freedom, which is responsible and can be accountable to Allah (Haniffah et. al., 2002). As a khalifah who holds fast to the principle of Tauhid in leading an Islamic business organization, it is natural that such a leader implements CSR (Muwazir et. al., 2006).

\section{Hypotheses}

Company size is the variable most often used for explaining the variation of social and environmental disclosure (Curuk, 2009; Gao et. aL, 2005; Joseph \& Taplin, 2011; Naser et. al., 2006; Sembiring, 2005). The result of almost all of these studies supports the hypothesis except Curuk (2009). Company size correlates positively with disclosure of social responsibility. The relation between company size and CSR disclosure is explained by agency theory. Big companies would voluntarily disclose more information to reduce agency cost (Naser et. al., 2006; Sembiring, 2005). Therefore, in order to test the relevance of company size to CSR disclosure, the following hypothesis is proposed: 
H1. Banks with larger assets would play greater role in social activities than banks with smaller assets. There is a positive relation between the magnitudes of bank assets with its role in social activities.

Studies on the factors influencing disclosure of social responsibility in Indonesia has come up with mixed results. Sembiring (2003) found that profitability does not have any impact on CSR disclosure. The variable of company size is found to have significant impact on disclosure of company social responsibility. Sembiring (2003) found similar results. The independent variables in that study are profitability, size, leverage, size of board of director and profile. The result shows that profitability and leverage do not have significant impact on CSR disclosure. Other variables (size of board of directors, company size and profile) have significant impact on CSR disclosure.

For the relation of profitability with CSR disclosure, the following hypothesis is proposed:

H2. Banks with higher profit will have greater role in social activities than banks with low profit. There is a positive relation between bank profitability and its role in social activities.

Previous studies have found that leverage is also correlated with disclosure level of CSR information, despite mixed findings. Roberts (1992) found positive correlation while Sembiring (2003) and Sayekti (2006) found negative correlation. Haniffa et. al., (2002) and Sembiring (2005) do not find correlation between leverage and CSR disclosure. While, Naser et. al., (2006) found a positive relation between leverage and social and environmental disclosure. Based on the report above, the following hypothesis is proposed for the relevance between leverage and CSR disclosure:

H3. Banks with low leverage tend to play greater role in CSR activities than banks with high leverage. The social role of banks is negatively related with bank's leverage.

According to Suciyati (2010), there is an inseparable relation between corporate social responsibility and good corporate governance since corporate social responsibility is one of the outcomes of corporate governance practice. Khan (2010) tries to explain the impact of governance corporate elements on the coverage of CSR disclosure for private banks in Bangladesh. The result shows that corporate governance generally has positive influence on CSR disclosure.

The mechanism for corporate governance is relevant for the disclosure of information (Bughsan, 2005). The mechanism for corporate governance, which is applied by Islamic banks, includes the formation of shari'a supervisory board, SSB (Dewan Pengawas Syariah, DPS). SSB is explained by Accounting and Auditing Organization for Islamic Financial Institutions (AAOIFI) in Governance Standard for Islamic Financial Institutions (GSIFI) No. 1 paragraph 2 as follows:

A shari'a supervisory board is an independent body of specialist jurists in figh almua'malat (Islamic commercial jurisprudence). However, the Shari'a supervisory board may include a member other than those specialized in figh almua'malat but who should be an expert in the field of Islamic Financial institutions and with knowledge of figh al-mua'malat...

The tasks and functions of shari'a supervisory board (dewan pengawas syariah, DPS) in an Islamic bank is to supervise and direct the activities of the Islamic bank so as to abide by the rules and principles of syariah established by the fatwa (decrees) of Dewan Syariah Nasional (DSN) and to report the result of its supervision to the DSN. It is expected that the larger the number of DPS member, the better the supervision provided by the board. In Indonesia, the number of DPS 
member according to central bank regulation, that is Peraturan Bank Indonesia No. 6/24/PBI/2004 is at least 2 persons and at the maximum 5 persons, while according to AAOIFI in GSIFI No. 1, the membership of SSB should at least be 3 persons. The existence of shari'a supervisory board (SSB) may lead to greater monitoring and thereby greater disclosures of CSR information, and the degree to which the SSB would influence CSR disclosures may also depend on the characteristics of this corporate governance mechanism (Haniffa \& Cooke, 2002; Ho \& Wong, 2001; Farook et.al., 2011).

Based on the discussion above, the following hypothesis is proposed:

H4. Banks with larger number of DPS (or SSB) members would play bigger role in CSR disclosure. Therefore, there is a positive between the number of DPS members and CSR disclosure.

Agency theory states that the principal-agent problem between shareholders and management occurs when management has a little ownership in the company. The structure of ownership also determines the level of monitoring and thereby the level of disclosure. (Jensen and Meckling, 1976). Agency theory predicts that there a positive association between the interests of management with voluntary disclosure. The greater management ownership in a company, the management is likely to be more actively pursuing the interests of shareholders that are he. A number of prior studies look at the effect of ownership structure on voluntary disclosure (Rulru1d et al., 1990; Eng dan Mak, 2003; El-Gazzar, 1998; Mitchell et al., 1995; McKinnon dan Dalimunthe, 1993; Schadewitz and Blevins, 1998; Farook et al.,2011).

Ownership in Islamic banks more dominated by investors who invest in shirkah funds temporary than investing in capital stock. Investors are more interested in Islamic banking services for a given outcome compared with the investment bank. Moreover investments in Islamic banks more accessible than equity (Farook et al., 2011). While the investment account holders do not have any formal voting rights, they nevertheless influence the level of monitoring of management 'vicariously' through shareholders (Archer et al. 1998). If the investment account holders are more interested than the shareholders in the bank's compliance with Islamic laws and principles, then the relative influence of the investment account holders will determine the extent to which the bank complies with Islamic laws and principles and consequently the level of disclosure presented by the bank.

Based on the discussion above, the following hypothesis is proposed:

H5. Islamic banks with a ratio of investment account holders to more actively participate in the disclosure CSR. There is a positive related between proportion ownership structures with CSR.

\section{Descriptive Analysis}

\section{a. Description of Statistical Data}

Based on the data obtained in annual report, we can identify banks disclosing and not disclosing CSR. The variable of CSR is a dichotomous one where banks' not disclosing CSR is coded as zero (0) and otherwise as one (1). From 2007 to 2010, it is known that $53.6 \%$ of banks has disclosed CSR while the remaining $46.4 \%$ does not. 


\section{b. Independent T-test}

Descriptive statistical analysis describes the result of t-test between banks disclosing CSR and those not disclosing CSR. The primary objective of this analysis is to determine whether one can distinguish between Islamic banks disclosing CSR and those not disclosing CSR based on the number of DPS members and financial characteristics, which includes company size, ROA and leverage. The t-test in this research is independent sample t-test since the two groups in this research is not related to one another. The result off t-test shows that the significance levels for Levene's test for some ratios are less than $p=.05$, which means that the variance of the two groups are different. Therefore, it is concluded in this research that equal variances are not assumed. The result of data processing is as follows:

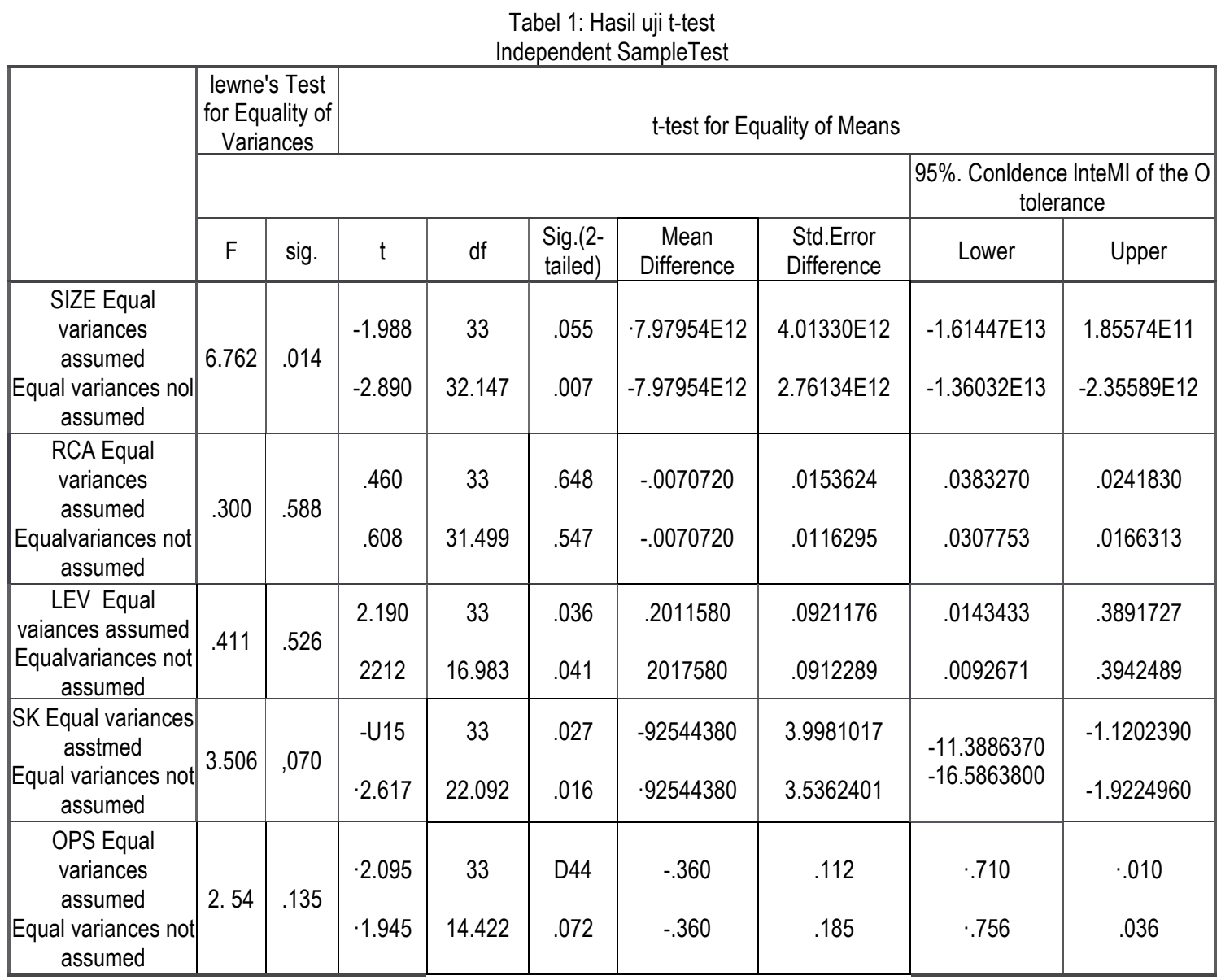

In order to determine whether there is a difference between banks disclosing CSR and those not disclosing CSR, one can examine the significance of two-tailed test. The analytical result of t-test shows that the variable of company size is significant at .014 and ROA is significant at .588 levels, leverage is found to be insignificant, ownership structure significant at 0.070 and number of DPS significant at 0.135 . Fifty percent of the independent variables is significant, meaning that financial characteristics can indeed distinguish between banks disclosing CSR and those not disclosing CSR.

\section{c. Analysis of Logit Model}

Analysis of logit model in this research is applied to determine the opportunity for distinguishing between banks disclosing CSR and those not disclosing CSR based on their financial 
characteristics. On the other hand, the dependent variable is dichotomous (dummy variable). The result of regression logistic analysis is as follows:

Table 2: Result Logistic Regression

Hosmer and Lemeshow Test

\begin{tabular}{|c|c|c|c|}
\hline Step & Chi-square & df & Sig. \\
\hline 1 & 1.944 & 7 & .963 \\
\hline
\end{tabular}

\begin{tabular}{|c|c|c|c|}
\hline Step & -2 Log likelihood & $\begin{array}{c}\text { Cox \& Snell } \\
\text { R Square }\end{array}$ & $\begin{array}{c}\text { Nagelkerke } \\
\text { R Square }\end{array}$ \\
\hline 1 & 32.535 & .234 & .336 \\
\hline
\end{tabular}

\begin{tabular}{|c|c|c|c|c|c|c|}
\multicolumn{7}{|c|}{ Variables in the Equation } \\
\hline & B & S.E. & Wald & df & Sig. & Exo(B) \\
\hline Step LOGSIZE & .566 & 1.007 & .315 & 1 & .074 & 1.761 \\
1 ROA LEV & 7.719 & 10.760 & .515 & 1 & .473 & 2249.826 \\
STRUKTUR & -2.454 & 2.395 & 1.050 & 1 & .305 & .086 \\
DPS(1) & .013 & .089 & .022 & 1 & .081 & .987 \\
Constant & 1.824 & 1.359 & 1.803 & 1 & .079 & .161 \\
& -4.287 & 12.689 & .114 & 1 & .735 & .014 \\
\hline
\end{tabular}

Variable(s) entered step 1 LOGSIZE, ROA, LEV, STRUKTUR, DPS

Therefore, the logit regression equation is as follows:

CSRit $=-4.287+0.566$ InSIZEit + 7.719ROAit- 2.454 LEVit + 1.824 DPSit + 0.013Skit + $\Sigma$ it

In order to evaluate whether the logit model has sufficient fit, we examine the output of Hasmer and Lamesshow test. From the statistical output, it turned out that the significance value is. 963>.1. The output from Cox-Snell R2 and Nagelkerke R have the same analogy with R-square in linear regression (Nachrowi, 2008). These show that $33.6 \%$ of the variance is explained by the model, while the rest is outside the model.

Based on the logit equation above, the intercept value of -4.287 , and this would mean that without the variables of DPS, company size, ROA and leverage, the value of CSR is 4.287 . From the result of logit calculation above, we get value of regression coefficient for company size is .566 with a significance of .074. This is consistent with the previous research by Brammer et. al., (2004) and Brown et. al., (2006) which found that the size of Islamic bank reflects the ability of a bank to attract customers so as to obtain financing from Islamic banks. In order to retain customers, Islamic banks must show that they have carried out their social responsibility towards the society and not simply gaining profit for their shareholders. For Malaysia (Masruki et. al., 2009), there is a tendency for banks with large assets to gain strong support for carrying out CSR. As a whole, bank size is a determinant of CSR disclosure in Malaysia. This is consistent with the findings from Febrina (2011) that company size is the only factor influencing social and environment policy disclosure for manufacturing companies in Indonesian Stock Exchange. The relation between company size and CSR disclosure can be explained by agency theory. A company would voluntarily disclose greater information to reduce agency cost (Naser et al., 2006; Sembiring, 2005).

The ROA variable has a positive regression coefficient of 7.719 but not significant at level 0.10 , where this sign shows that a one unit increase in ROA would increase the level of CSR disclosure of 7.719 unit, other variables assumed to be constant. A significance of .473 is far above $\alpha=10 \%$. The result above is consistent with Sembiring (2005) and Febrina (2011), who found that profitability does not have significant impact on social and environmental responsibility disclosure 
of companies, meaning that higher profitability does not improve the policy of social and environmental responsibility disclosure since a profitable company would consider it undesirable to report things that may detract from the information on its financial success. On the other hand, this may open the opportunity for agency conflict which would result in agency cost for the company. Calculation shows that the regression coefficient of leverage is a negative 2.454 with a significance of .305 , meaning that between CSR and leverage, there is a statistically not significant impact on the level $a=10 \%$. This contradicts the third hypothesis of this research, which states that banks with low leverage will have greater role in social activities compared to banks with high leverage.

The value of regression coefficient for DPS is 1.824 with a significance of .079 , which means that if the number of DPS member increases one more, then it would increase the level of CSR disclosure as much as 1.824 but there is a statistically significant impact on the level $\alpha=10 \%$. The result of this research is consistent with Haniffa \& Cooke (2002), Ho \& Wong (2001), which show that the existence of DPS in Islamic banks would indicate the magnitude of CSR disclosure, since the existence of DPS would result in higher supervision on the activities of Islamic bank, including CSR activities, this is consistent with the research of Farook et. al., (2011), which explains the factors influencing CSR disclosure of Islamic banks in Middle Eastern countries, and which found that the factors such as the existence of shari'a supervisory board, political and social freedom of the society and the magnitude of deposit investments against total assets are the significant variables in explaining CSR disclosure.

One of the tasks of DPS is to supervise and direct the activities of Islamic banks so that they abide by the rules and principles of shari'a. Considering that in Islam, business transaction cannot be separated from social responsibility towards the society therefore the greater number of DPS member, it is expected that the supervision and direction would be better and this would make an impact on CSR disclosure.

The ownership structure variable has a positive regression coefficient of 0.013 which means that if ownership structure increases one more, then it would increase the level of CSR disclosure as much as 0.013. These results are consistent with fifth hypothesis that there is a positive relationship between ownership structure and CSR disclosure. As we know that the larger ownership structure, the greater shareholder monitoring the performance management. It is necessarily correlated with the extent of the disclosure of bank performance.

Seen from the perspective of stakeholder theory, a company is not an entity, which operates merely for its own interest but must provide benefit for its stakeholders. In this way, the existence of a company is strongly dependent on the support from stakeholders to the company (Ghozali \& Chariri, 2007). When the company realizes that stakeholder interest is important for company survival then the company would not simply focus solely on gaining profit for the shareholder and management but would also consider wider stakeholders. Therefore, the company should disclose CSR so that the information can be used by stakeholders and eventually creates good image for the company. On the other hand, CSR disclosure shows that accounting information is a signal for the concern of the company towards stakeholders.

\section{CONCLUSION}

From the result of descriptive analysis and t-test, it has been shown that the variable of company size, DPS and ownership structure are both significant on .014, .0.035 and .070 level and these are still below $a=10 \%$, while ROA, leverage is not significant. Fifty percent of the independent 
variables are significant, meaning that DPS and financial characteristics (size, ROA and leverage) can explain the distinction between banks disclosing CSR and those not disclosing CSR. The legit model here has fulfilled the assumptions of model fit based on the output of Hasmer and Lamesshow test with a significance of .963> .10 and a Nagelkerke R of 33.6\%, which means that the existing model can explain $33.6 \%$ while the rest is outside the model.

The variable of DPS members, ownership structure and company size are determinants of CSR disclosure, where higher number of DPS members and greater size of the bank would increase the level of CSR disclosure. This supports the findings of Brammer et. al., (2004), Brown et. al., (2006), Masruki et. al., (2009), Febrina (2011) and (Farook, et al: 2011). Leverage is found to be positive and significant at $a=10 \%$, meaning that increase in leverage would have an impact on CSR disclosure. This finding contradicts the first hypothesis, which states that banks, with low leverage tend to play greater role in CSR activities. ROA is found to have negative but insignificant impact, which means that higher ROA does not improve the policy of company social responsibility disclosure. 


\section{References}

AAOIFI (2003). Accounting, Auditing \& Governance Standards for Islamic Financial Institutions. $4^{\text {th }}$ Edition. AAOIFI. Bahrain.

Adams, M. and HardWick, P. (1998). An Analysis of Corporate Donations: United Kingdom evidence. Journal of Management Studies. 35 (5). 641-654.

Ahmad, K (2000). Islamic Finance and Banking: The Challenge and Prospects. Review of Islamic Economics, 9, 57-82.

al-Jawziyyah, I.Q. (1995). l'lam al-Muwaqqi'in. Kaherah. Aupperle, K E., Carroll, A.B. and Hatfield, $J$ J. D. An empirical examination of the relationship between corporate social responsibility and profitability. Academy of Management Journal. 28 (2), 446-463.

Anwar, Samsinar. Haerani, Siti dan Pagalung, Gegaring. (2009). Pengaruh Pengungkapan CSR terhadap Kinerja Keuangan dan Harga Saham. Jakarta: Working Paper.

Beekun, Rafik Issa (1997). Islamic Business Ethics. Virginia: International Institute of Islamic Thought. Pp.60-63.

Brammer, S. and Millington, A. (2004). The Development of Corporate Charitable Contributions in the UK: A stakeholder Analysis. Journal of Management Studies. 41 (8). 1411-1434.

Brigham, Eugene, F. (2010). Dasar-dasar Manajemen Keuangan Edisi Sebelas. Jakarta: Salemba Empat.

Brown, E., Helland, E. and Smith, J.K. (2006). Corporate philanthropic practices. Journal of Corporate Finance.

Business Corporations - An Islamic Perspectives", in Nik Mustapha Nik Hassan and Shaikh mohd Saifuddeen Shaikh Mohd Salleh (eds.), Corporate Governance from the Islamic Perspective. Kuala Lumpur: Institute of Islamic Understanding Malaysia (IKIM). pp. 31-34.

Bugbsan. (2005). Corporate Governance, Earning Management and the information content of Accounting Earning: Theoritical Model and Empirical Test. Dissertation, unpublished. Australia : Bond University. Queensland

Carroll, A.B. (1979). A three-dimensional conceptual model of corporate social performance. Academy of Management Review. 4, 496-505.

Carroll, A.B. (1991). The pyramid of corporate social responsibility: toward the moral management of organizational stakeholders. Business Horizons. Jul-Aug, 42.

Cochius T. (2006). Corporate Social Responsibility in Dutch SMEs: Motivations and CSR Stakeholders. Final thesis Maasticht University Faculty of Economics and Business Administration.

Daniri, Mas Achmad. (5 Juni 2008). Standarisasi Tanggung Jawab Sosial Perusahaan (Bag I). http://www.madani-ri.com/2008/01/17/standarisasi-tanggung-jawab-sosial-perusahaan-bagi 
1.

Deegan, C. (2000). Financial Accounting Theory. NSW: Mc Graw-Hill Australia

European Commission. (2001). Promoting a European Framework for Corporate Social Responsibility, European Commission. URL http://europa.eu.int/comm/employment_social/social/csr/greenpaper_en.pdf

Farook, Sayd., Hassan, Kabir and Lannis. (2011). Determinant of Corporate Social Responsibilty Disclousure: case of Islamic Banks. Journal of Islamic Accounting and Business Research. 2(2):114-141. Emerald Group Publishing Limite.

Febrina dan Suaryana, A. (2011). Faktor-faktor yang mempengaruhi kebijakan pengungkapan tanggungjawab sosial dan lingkungan pada perusahaan manufaktur di BEl. Simposium Nasional Akuntansi XIV. Aceh.

Freeman, R. (1984): Strategic Management: A Stakeholder Approach, Pitman, Boston, MA.

Gambling, T.E. and Karim, R.A.A. (1986). Islam and Social Accounting. Journal of Business Finance and Accounting. 13 (1): 39-49.

Gao, S.S., Guedhami, O., Kwok, C.C.Y., \& Mishra, D.R. 2011. Does Corporate Social Responsibility Affect Cost of capital. Journal of Banking \& Finance. 1-12.

Ghazali dan A. Chariri. (2007). Teori Akuntansi. Semarang: Universitas Diponegoro.

Haniffa, R. (2001). Social Responsibility Disclosure: An Islamic Perspective. Discussion paper. University of Exeter, UK.

Hassan, Abul \& Harahap, Sofyan Safrie. (2010). Exploring Corporate Social Responsibility Disclousure: the case of Islamic Banks. International Journal of Islamic and Middle Eastern Finance and Management , 3(3): 203-227.

Harrison, J. S. \& Freeman, R. E. (1999). Stakeholders, Social Responsibility and Performance: Empirical Evidence and Theoretical Perspectives. Academy of management Journal, 42(5): 479-485.

Hills, C.W.L. and Jones, T.M. (1992). Stakeholder-agency theory. Journal of Management Studies, 29(2): 131-154.

Hossain, M., Perera, M. H. B. and Rahman, A. R. (1995). Voluntary discolosure in the annual reports of New Zealand Companies. Journal of International Financial Management and Accounting, 6(1): 69-87.

Ho, S.S.M. and Wong, KS. (2001). A study of the relationship between corporate governance structures and the extent of voluntary disclosure. Journal of International Accounting, Auditing \& Taxation, 10: 139-56.

International Association of Islamic Banks (IAIB). (2001). Directory of Islamic Banks and Financial Institutions. IAIB. Jeddah. 
Jensen, M.C. and Meckling, W.H. (1976). Theory of the firm: Managerial behavior, agency costs and ownership structure. Journal of Financial Economics. 3 (4): 305-360.

Joseph, C.. \& Taplin. 2011. The Measurement of Sustainability Disclosure: Abundance versus occurrence. Accounting forum, 35, 19-31.

Lewis, M. K (2001). Islam and Accounting. Accounting Forum. 25 (2). 103-127. Luo, X and Bhattilcharya, C. B. (2006). Corporate Social Responsibility, Customer Satisfaction and Market Value. Journal of Marketing. 70 (October). 1-18.

Lynes, J.K, \& Andrachuk, M. (2008). Motivation for Corporate Social and Responsibility: a case study of Scandinavian Airlines. Journal of International Management, 14: 377-390.

Naqvi, Syed Nawab Haider. (1981). Ethics and Economics: An Islamic Synthesis. Leicester: The Islamic Foundation.

Maali, B., Casson, P. and Napier, C. (2003). Social Reporting by Islamic Banks. Discussion papers in Accounting and Finance. University of Southampton.

Masruki, Rosnia., Zakaria. 2009. Value Morris, R.D. (1987). Signalling, agency theory and accounting policy choice. Accounting and business Research, 18(69): 47-59.

Morris, R.D. (1987). Signalling, agency theory and accounting policy choice. Accounting and business Research, 18(69): 47-59.

Muwazir, Mohd Rizal, Muhamad, Rusnah and Noordin, Kamaruzaman (2006). "Corporate Social Responsibility Disclosure: A Tawhidic Approach". Jurnal Syariah. 14(1): 125-142.

Priyatno, Duwi. (2009). SPSS untuk Analisis Korelasi, Regresi, dan Multivariate. Yogyakarta: Gava Media.

Rahman, A.R.A. and Goddard, A. (1998). "An Interpretive Inquiry of Accounting Practices in Religious Organisations". Financial Accountability and Management. 14(3): 184-190.

Reksodiputro, Mardjono. (2004). Makalah Loka-karya Nasional Departemen Luar Negeri RI, dengan tema "Peran sektor usaha dalam pemenuhan, pemajuan, dan perlindungan HAM di Indonesia". Jakarta: Hotel Borobudur.

Schermerhorn, John R. (1993). Management for Productivity. New York: John Wiley \& Sons.

Sembiring, E. R. (2005). Karakteristik Perusahaan dan Pengungkapan Tanggung jawab Sosial: Studi empiris pada Perusahaan yang tercatat di BEJ. Solo: Seminar Nasional Akuntansi.

Usman, Bahtiar. (2003. Analisis Rasio Keuangan dalam Memprediksi Perubahan Laba pada Bank-Bank di Indonesia. Media Riset Bisnis \& Manajemen, Vol 3 No. 1

Usmani, M. T. (2002). An Introduction to Islamic Finance Arab and Islamic Law Series. Amsterdam: Kluwer Law International.

Westerfield, Ross and Jordan. (2009). Pengantar Keuangan Perusahaan Edisi 8. Jakarta: 
Relevance of Financial Performance and Good Corporate Governance Determinantof

Salemba Empat.

Wineberg, Danette and Phillip H. Rudolph. (2004). "Corporate Social Responsibility - What Every In House Counsel Should Know", dalam ACC Docket.

Waryanti. (2009). Pengaruh Karakteristik Perusahaan Terhadap Pengungkapan Sosial Pada Perusahaan Manufaktur di Bursa Efek Indonesia. Skripsi SI Akuntansi UNDIP. 